Medievalia 24 (202I), 7-IO - ISSN: 20I4-84IO (digital)

DOI: https://doi.org/I0.5565/rev/medievalia. 553

\title{
EL LIBRO DE LA DESTRUICIÓN DE JERUSALÉN Y LA HISTORIA DEL VASCUENCE
}

\author{
THE LIBRO DE LA DESTRUICIÓN DE JERUSALÉN \\ AND BASQUE HISTORY
}

\author{
David Hook \\ University of Oxford, Faculty of Medieval \& Modern Languages \\ davidhook@hotmail.com \\ https//:orcid.org.0000-0003-7296-2220 \\ Recepción: II/O6/202I - Aceptación: Io/09/202I
}

\section{Resumen}

Para el autor de un Nobiliario del siglo xvi, el Libro de la destruición de Jerusalén era una obra de narración histórica fidedigna, no una ficción.

\section{Palabras clave}

Recepción / interpretación textual, Vespasiano, vascuence.

\begin{abstract}
For the author of a s. XVI ${ }^{\text {th }}$ treatise on aristocracy, the Libro de la destruición de Jerusalén was a serious historical work, not a fictitious narrative legend.
\end{abstract}

\section{Keywords}

Textual Reception / Interpretation, Vespasian, Basque Language.

Los hallazgos fortuitos pueden ser tan productivos como la búsqueda sistemática cuando se trata de la colección de la evidencia para la recepción y el uso posterior de un texto medieval. Buen ejemplo de ello es el hecho de que, durante la preparación de un estudio del Tizón de la nobleza de España del cardenal Francisco de 
Mendoza y Bobadilla, encontré en un nobiliario del siglo XVI un dato útil para la historia del Libro de la destrucción de Jerusalén, muy difundido durante los siglos medievales.

El Manuscrito 3094 conservado en la Biblioteca Nacional de España (Madrid), del siglo Xvi, lleva el título de Blasón de armas de todos los reyes, emperadores, caballeros e hidalgos de España. Según la breve descripción del Inventario general de manuscritos de la BNE (t. X, pp. I7-I8), perteneció a D. Fernando José de Velasco. En un párrafo del manuscrito que discute la cuestión de los orígenes de los vascos y su idioma, que sirve de introducción a la descripción de las armas de familias de la región, leemos esto:

algunos dicen que esta tierra fue poblada de aquellas barcas que titus, y Vespesiano, hecharon de gerusalen. Y aun dicen que los hiço deslenguar y que por tanto hablan aquel lenguaxe mas apartado. Lo qual niega la ystoria de la conquista de Jerusalem. quando fue destruyda que no dicen que les cortaron las lenguas ni menos de aquellas barcas allegasen alli. porque la vna aporto a burdeos y la otra a yngalaterra y la otra en narbona: y por esto parece yncierto. y si quieren descir que la destruycion de Jerusalen fue antes que la de troya no es ansi porque la de troya fue en la quarta hedad [....]. y fueron los muros de jerusalen derrocadas en la sesta hedad. (Manuscrito 3094 de la Biblioteca Nacional de España, pp. 53-54 de la paginación antigua, láminas 28-29 de la reproducción digital de la Biblioteca Digital Hispánica de la Biblioteca Nacional de España.)

Casi lo mismo se encuentra en el Manuscrito 306I, identificado por el Inventario general de manuscritos (t. X, p. Io) como el Nobiliario de Juan Pérez de Vargas, también del siglo xvi:

Algunos quieren decir que esta tierra fue poblada de aquellas barcas que Tito y Vaspasian[o] echaron de Jerusalén y fueron deslenguados y con lenguaje extraño y por ello hablaban aquel lenguaje tan apartado. Pero esto lo niega la otra historia, la de la conquista de Jerusalén que no dice que algunas de las barcas hubiese aportado ahí y menos que les hubieran cortado las lenguas, salvo una barca que aportó en Burdeos, otra en «Ynagalaterra» y otra en Narbona (Escobar Olmedo, 1999: p. 75)

Amén de su interés como testimonio de las especulaciones contemporáneas sobre los orígenes del vascuence, el pasaje citado constituye otro fragmento de evidencia para la difusión y recepción de una versión legendaria de la destrucción de Jerusalén por los romanos que circulaba en manuscritos e impresos por los

I Véase para datos adicionales sobre la fuente textual Escobar Olmedo 1999, pp. 73 y I83. 
países europeos durante la Edad Media y el siglo xvi. En España, se conocen ediciones y/o copias manuscritas en castellano y catalán bajo varios títulos: $\mathrm{La}$ estoria del noble Vaspasiano enperador de Roma, Libro de la destruición de Jerusalén, La destrucció de Hierusalem. De las tres familias textuales peninsulares que describí en mi edición de la Versión II, ésta tuvo la mayor y más duradera difusión; el episodio de los barcos se encuentra en las ediciones impresas castellanas y una copia manuscrita tardía, y también en la tradición manuscrita catalana. Típica es la narración de este episodio en la edición de Toledo [Juan Vázquez, I49I-94 (c. I492)]:

$\&$ fecho esto, fizo aparejar tres naues. \& en cada vna destas tres naues fizo poner los judios entre onbres e mugeres e criaturas; $\&$ sin marineros ningunos, $\&$ sin onbres que pudiesen rregir las naues [en] las mares, \& menos de viandas, fizoles salir del puerto que hes delante el castillo de Cayfas $\&$ dexoles yr. Mas nuestro señor Jhesu Christo, que quiso que la su muerte fuese rremenbrada, saluo todas las naues \& quantos dentro eran. \& vino arrivar vna naue en Inglatera $\&$ la otra en Burdeus \& la otra en Narbona, \& todos salieron sanos \& saluos (Hook, 2000, p. 249; 11. I542-I55I).

La version catalana del Manuscrito 7Io de la Biblioteca de Catalunya (Barcelona), tiene los mismos puntos de llegada, pero en secuencia distinta: «la una nau vingue arribar en lo grau de Narbona, e la segona arriba a Bordeu, e la terça en Anglaterra.» (Hook, 2000, p. I88; 11. I37I-I373).

Es evidente que el autor del texto conservado en los manuscritos 306r y 3094 de la BNE de Madrid conocía una versión de esta rama de la tradición textual de la leyenda: el episodio citado no se encuentra en la Versión III, incluida en el Gamaliel (Delbrugge, 2020); no se conoce ningún testimonio castellano de la Versión I, cuyas únicas manifestaciones peninsulares (el Manuscrito Ripoll I55 del Archivo de la Corona de Aragón (Barcelona), y un manuscrito subastado en Nueva York) forman otra rama de la tradición manuscrita catalana. ${ }^{2}$

La alusión documentada aquí tiene doble interés, porque el autor utiliza dicha leyenda, tratándola con todo el respeto que merecería una fuente fidedigna de datos históricos, para refutar otra tradición («algunos dicen...») basada en la misma leyenda de la expulsión por Vespasiano de tres barcas llenas de judíos. Es obvio que para nuestro autor la obra que llama la Historia de la conquista de Jerusalén (nótese, sin embargo, que también utiliza la frase «la destruyción de Jerusalen» en su texto) era una obra seria de historia, no una ficción. Además

\footnotetext{
${ }^{2}$ Véase Hook 2010.
} 
de añadir esta alusión al fichero de evidencia para la difusión e interpretación del Vespasiano, nos quedará la tarea de identificar la tradición anterior sobre los vascos y el vascuence que rechaza nuestro autor mediante su lectura cuidadosa de esta duradera, y muy conocida, leyenda medieval. Y finalmente, tenemos aquí otro paralelo para el fenómeno de la «lectura profunda» de textos ficticios estudiado por Pedro Cátedra. ${ }^{3}$

FUENTES

Manuscrito 3094 de la Biblioteca Nacional de Espańa. En línea: <bdh.bne.es/ bnesearch/detalle/bdhoooori8745> [Consulta: 3 de julio de 202I].

\section{BIBLIOGRAFÍA}

Cátedra, P., 20I6: «Lectura profunda de ficción caballeresca en tiempos de Quijano", Historias fingidas, 4, pp. 2I-39.

Delbrugge, L. (ed.), 2020: A Scholarly Edition of the Gamaliel (Valencia: Juan Jofre, I525), The Medieval and Early Modern Iberian World, 73, Leiden.

Escobar Olmedo, A. M. (ed.), I999: El Tizón de la Nobleza de España por el Cardenal Francisco de Mendoza y Bobadilla, Obispo de Burgos, MDLX, México.

Hook, D. (ed.), 200o: The Destruction of Jerusalem. Catalan and Castilian Texts, King's College London Medieval Studies, XVI, Londres.

Hook, D., 20IO: "Problemas ético-ecdóticos de un manuscrito medieval», en J. M. Fradejas Rueda et al. (eds.), Actas del XIII Congreso Internacional, Asociación Hispánica de literatura Medieval, 2 tomos, Valladolid, II, pp. 997-IOII.

${ }^{3}$ Véase Cátedra 20r6, pp. 2I-39. Agradezco a los anónimos evaluadores de Medievalia la gentileza de haberme llamado la atención sobre esta referencia bibliográfica. 